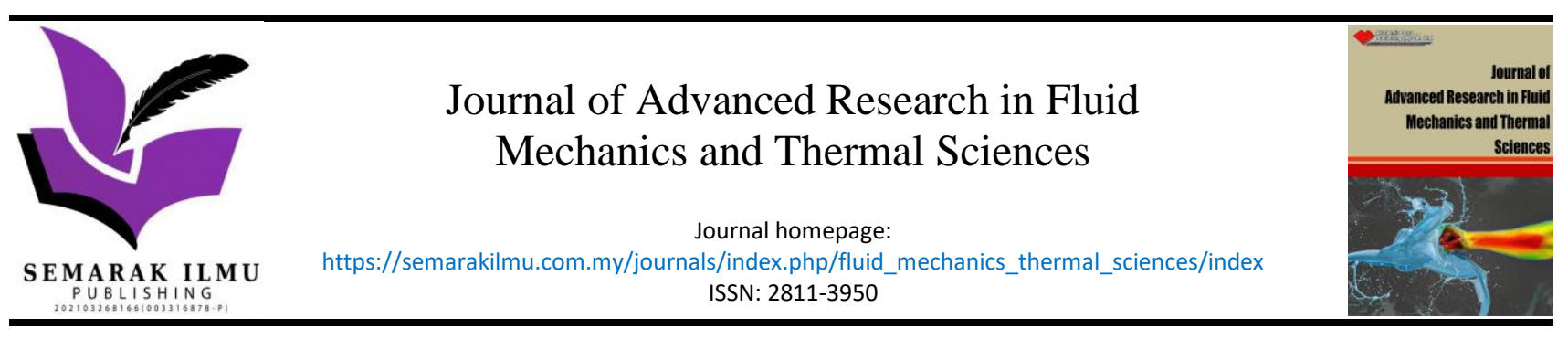

\title{
Natural Dyes Utilization and Production Technology for Dye-Sensitized Solar Cell
}

\author{
Adhi Kusumastuti ${ }^{1,}{ }^{*}$, Samsudin Anis ${ }^{1}$, Monna Rozana ${ }^{2}$ \\ Faculty of Engineering Universitas Negeri Semarang, Kampus UNNES Sekaran, Gunungpati, 50229 Semarang, Indonesia \\ Research Unit for Clean Technology, Indonesian Institute of Sciences, Komplek LIPI Bandung Gedung 50, Dago, 40135 Bandung City, Indonesia
}

\section{ARTICLE INFO}

\section{Article history:}

Received 28 July 2021

Received in revised form 3 December 2021

Accepted 25 December 2021

Available online 27 January 2022

\section{Keywords:}

Natural dyes; Dye-Sensitized Solar Cell; sensitizer; powder production technology

\section{ABSTRACT}

Dye-sensitized solar cell (DSSC) provides high ability of renewable energy generation. One of the main factors affects the performance of DSSC is the type of dye applied as a sensitizer. Natural sensitizers have become a major concern due to the widely availability in the world and environmentally friendly characteristic. However, the need to improve the natural dyes based DSSC performance is very important. This review was conducted to present the recent studies in natural dyes utilization and performance for DSSC application. The short overview of DSSC is also provided. In addition, alternative natural dyes in the form of powder, process and production technology with their strengths and the weaknesses are also discussed.

\section{Introduction}

The increase of energy consumption in Indonesia in the interval of a decade reached about $82 \%$ [1]. Currently, the need of energy is supplied by conventional and non-renewable energy sources, such as coal, and gas and oil. Despite the decrease of energy sources, the need of energy keeps on increasing. It was reported that the coal reserves are only available for another 6 decades [1]. To overcome this problem, an alternative energy source is needed to reduce the dependence on nonrenewable energy sources.

Among the growing rapid renewable energies are wind and solar energies. The renewable energy sources are clean and freely available. The main obstacle with these two types of energy is the inconsistent supply. Wind turbine requires large land area, the development of wind farms on productive land raises problem to the surrounding [2]. The land use for wind generator decreases the agricultural and settlements areas. Solar energy is only available during the day when the weather is sunny (not cloudy or rainy). Meanwhile, wind energy is available at times that are often unpredictable (sporadic), and fluctuate greatly depending on the weather or season. To overcome the above problems, hybrid techniques are widely used to combine several types of power plants, such as wind, solar and diesel energy generation, wind and solar energy generation, wind and diesel

\footnotetext{
* Corresponding author.

E-mail address: adhi_kusumastuti@mail.unnes.ac.id
} 
energy generation. In this hybrid technique, the battery is generally used as temporary energy storage, and a controller is used to optimize the energy consumption of each source and the battery, according to the load and energy availability of the energy source used. Islam et al., [3] presented previous studied about improvement of conversion efficiency of CZTS solar cells and future application of thin film solar cell.

The application of solar energy in Indonesia is obstructed by the high investment costs. In addition, the main equipment for solar power generation, i.e., photovoltaic modules, is still imported, while the low efficiency of photovoltaic modules of about $16 \%$ resulted in the very high price of solar energy. Therefore, to increase the installed capacity of solar power generation, government regulations need to be issued. The addition of local content supporting tools to the manufacture of solar power generation is another alternative. It is believed to reduce the cost of solar power generation that becomes more reasonable as an alternative power plant [4].

Silicon solar cells are currently the most widely used solar cells, as the first generation solar cells. However, the high cost of producing silicon makes its consumption cost more expensive than that of fossil energy sources. The generation of low costs solar cells could be prepared from organic semiconductor materials. This is because organic semiconductors can be synthesized in large quantities. However, its efficiency is far below that of silicon solar cells. Therefore, research on organic material as material for solar cells still needs to be developed.

Given these weaknesses, a dye-sensitized solar cell (DSSC) was developed, which is a thirdgeneration type of solar cell that utilizes photo electrochemical principles. This type of solar cell is believed to be able to provide alternative energy concepts at a more affordable cost of production and with simpler fabrication technology than its predecessor solar cells made from crystalline silicon.

Based on the description above, it is important to study the current progress of the development of natural dyes-based DSSC as a renewable energy source. Therefore, the aim of this study is to review the literature on the use of natural dyes on DSSC performance, and their advantages and disadvantages for DSSC applications. Moreover, alternative form of natural dyes, production technology, and their advantages and disadvantages are also discussed.

\section{DSSC Overview}

The DSSC structure consists of an anode photo electrode, a counter electrode used as a cathode, sensitizer, and electrolyte as given in Figure 1 using Titanium dioxide $\left(\mathrm{TiO}_{2}\right)$ (semiconductor) based electrode.

The two electrodes of DSSC i.e., an anode or photo or working electrode and a cathode or counter electrode, generally made of transparent conductive glass coated with transparent conductive oxide such as Titanium dioxide, Indium or Fluorine-doped tin oxide. The transmission of indium doped tin oxide (ITO) is higher than that of fluorine doped tin oxide (FTO) while the resistance of FTO sheets is smaller than that of ITO. The resistance of ITO sheets increases drastically by the increase of temperature during the sintering process, while the resistance of FTO sheets remains the same during the sintering process. $\mathrm{TiO}_{2}$ is commonly utilized in the applications of solar energy. This is due to the large band gap, suitable band edge levels for charge injection and extraction, long lifespan of excited electrons, exceptional resistance to photo corrosion, nontoxicity and low cost fabrication process. Naturally, crystalline $\mathrm{TiO}_{2}$ is available in the forms of anatase, rutile, and brookite. Anatase is the most suitable type for DSSC application for its superior charge transport nature [6]. 
DSSC performance is measured by several factors, i.e., open circuit voltage, short circuit current, charge factor, maximum voltage, and maximum cell current. When sunlight hits the DSSC surface, the dye molecules collect photons and produce excited electrons. Sensitizer inserts the excited electrons into conduction band of nanoporous semiconductor film. The lost-electrons dye molecule is then oxidized. The injected electrons move through a thin non-porous $\mathrm{TiO}_{2}$ film towards transparent conductive electrode (working electrode). Electrical energy is sent, followed by the return of electrons through the external load, reach the counter electrode, and complete the entire circuit.

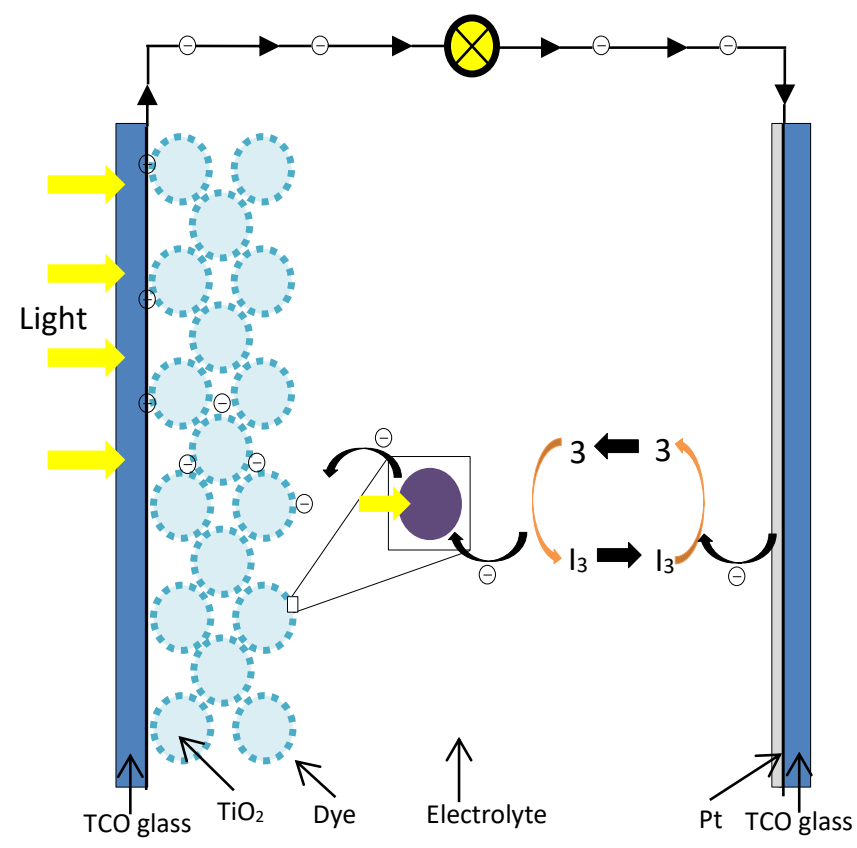

Fig. 1. Scheme of Dye Sensitized Solar Cell [5]

Dye concentrated solar cells have received increasing attention regarding their ability to generate renewable energy due to their simple and easy fabrication as well as low cost of cell production. In the last few years, many researchers have concerned in the research of DSSC. The system has high photovoltaic performance, especially at low light environment. Moreover, it is also flexible in terms of color and display. The simple fabrication procedure and low cost process are other value-added of the system.

Sensitizer absorbs solar radiation that increases cell conductivity. The sensitizer, composed of carboxyl and hydroxyl groups needed for proper binding of semiconductor, exhibits maximum absorbance of the visible solar radiation area to infrared area and not rapidly degraded [7]. Sensitizers can be metal complexes, metal-free organic compounds, and natural sensitizers. Metal sensitive sensitizers are expensive, rare and toxic, although they show the highest cell efficiency $[8,9]$. Figure 2 describes the highest efficiency of $11-12 \%$ that was obtained by applying DSSC sensitized by Ru-containing compounds $[10,11]$. 


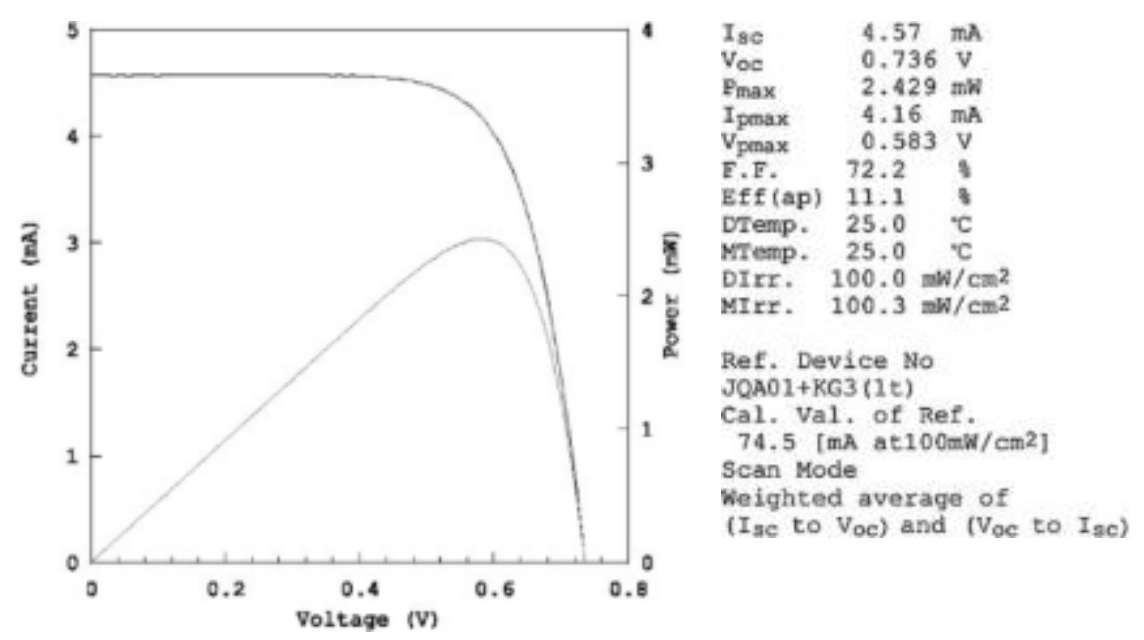

Fig. 2. Performance of Dye Sensitized Solar Cell [11]

\section{Natural Dyes-based DSSC}

Plants generating raw materials of natural dyes are widely available in the world. Natural dyes extensively applied in the fields of food, clothing and medicine. Application of natural dyes as a medium for light absorption in Dye Sensitized Solar Cells (DSSCs) is also a major concern of researchers. As sensitizer, dye plays an important role in absorbing sunlight and converting solar energy into electric energy. The performance of dye-concentrated solar cells is mainly based on the dye used as a sensitizer.

Some studies of natural dyes and their effect on various performance parameters of DSSC have been carried out [12-16]. Das et al., [17] studied the use of several natural dyes from Malabar spinach seeds, red spinach leaves, and pomegranate leaves as sensitizers. As the electrode, ITO glass coated with TiO2 sol-gel paste was used. The electrodes were immersed in the dye solution overnight. Characterization was carried out on the structure, morphology, capacitance, dielectric constant and impedance as well as electrode current and voltage as a function of the type of sensitizer. It was found that the Malabar seed extract was the most efficient as a sensitizer to solar energy converters. Meanwhile, Godibo et al., [18] used natural dyes from several kinds of flowers to assess their efficiency as sensitizer. The performance of natural dyes as sensitizers was measured based on short circuit current $\left(\mathrm{J}_{\mathrm{SC}}\right)$, open circuit voltage $(\mathrm{V})$, charging factor $(\mathrm{FF})$, and power conversion efficiency $(\eta)$. In general, as sensitizers, natural dyes are considered promising because they are environmentally friendly, low production costs, and energy efficient.

Extraction of spinach leaves was carried out using acetone as solvent, while extraction of red cabbage and onion skin was carried out using water as solvent [14]. The pigments of red spinach, cabbage, onion skin are chlorophyll and anthocyanin. The dye was characterized using UV-vis absorption, FTIR, and photoluminescence spectroscopy. The dye extract was used to sensitize solar panels. The degradation of power conversion efficiency was monitored during the week. The study also investigated the effect of $\mathrm{TiO}_{2}$ mesoporous layer on efficiency. The interface layer of natural dye and $\mathrm{TiO}_{2}$ was tested using electrochemical impedance spectroscopy.

Natural dye extract of pomegranate was used as sensitizer which is low cost and environmentally friendly. The chemical composition, structure, morphology and optical characteristics of FTO glass coated with $\mathrm{TiO}_{2}$ and pomegranate dye were tested by atomic force microscopy, scanning electron microscope (SEM), energy-dispersive x-ray spectroscopy, uv-vis and fluorescence spectroscopy. The results showed an increase in the conversion of solar energy into electricity [13]. 
A photo electrode as a sensitizer was developed with several types of natural dyes to increase the efficiency of solar cells [15]. Extraction of natural dyes was carried out by maceration technique for a day with methanol as solvent. Photovoltaic characteristics such as efficiency, charge factor, open circuit voltage and short circuit were assessed using a solar simulator and a source unit of measurement.

Pigments extracted from pure carminic acid, papaya peel and microalgae Scenedesmus obliquus were tested as Titania solar cell sensitizers. Papaya peel extract and chlorophyll extract obtained from the microalgae Scenedesmus obliquus were tested for the first time as a sensitizer on Titania solar cells. It was found that CA-sensitive cells provided good photo generation despite having recombination problems. $\mathrm{PA}$ and $\mathrm{Chl}$ sensitive cells present little photo generation but high recombination resistance (Rrec) [16].

The study conducted by lqbal et al., [19] revealed the progress of DSSC performance by incorporating natural photosensitizers such as chlorophyll, anthocyanin, flavonoids, carotenoids, and betalains extracted from various fruits, vegetables and flowers. Cost effectiveness and easy synthesis make natural dyes a good competitor to synthetic dyes. Application of natural dyes as sensitizer in the DSSC was recommended due to the higher efficiency for the next generation of photovoltaic devices. El-Ghamri et al., [20] reported their study about application of some plants as natural dyes for DSSC. They compared the performance of Safflower (Cathumus tincrorius), Senna (Cassia angustifolia), Calumus draca (Dracaena oinnabari), Carya illinoensis, Rheum, Roselle (Hibiscas sabdarriffa), Rosa damascena, and Runica granatum as DSSC's dye. Evaluation on the performance of each natural dye in term of current density voltage revealed that safflower provides the highest photo electrochemical performance $\left(\mathrm{J}_{\mathrm{sc}}=1 \mathrm{~mA} / \mathrm{cm}^{2}, \mathrm{~V}_{\mathrm{oc}}=0.390 \mathrm{~V}, \mathrm{FF}=0.24\right.$, and $\left.\eta=0.1\right)$. Safflower was the applied in the following study on the research. The sintering temperature of photo electrode was varied from $250^{\circ}$ to $600^{\circ} \mathrm{C}$ at the interval of $50^{\circ} \mathrm{C}$. After sintering process, the sample was dyed in safflower extract to investigate the best performance of photoelectrical response at $100 \mathrm{~mW} / \mathrm{cm}$. It is illustrated in Figure 3 that the highest response was generated by the system sintered at $400^{\circ} \mathrm{C}$. Higher photocurrent density could be achieved by loading more dye, resulted by large surface area and high porosity. The deterioration of cell efficiency could occur as a result of excessive temperature which leads to the reduction of surface area. Summary of previous studies on the application of natural dyes for dyes sensitizer is given in Table 1.

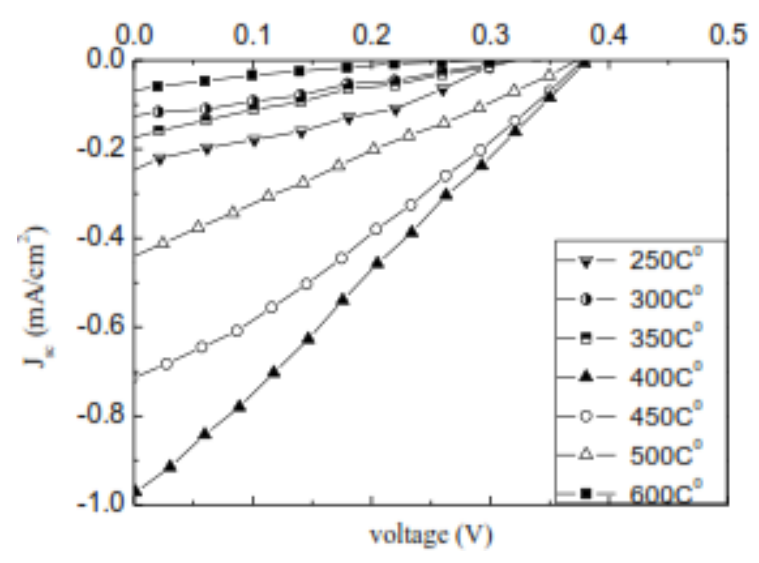

(a)

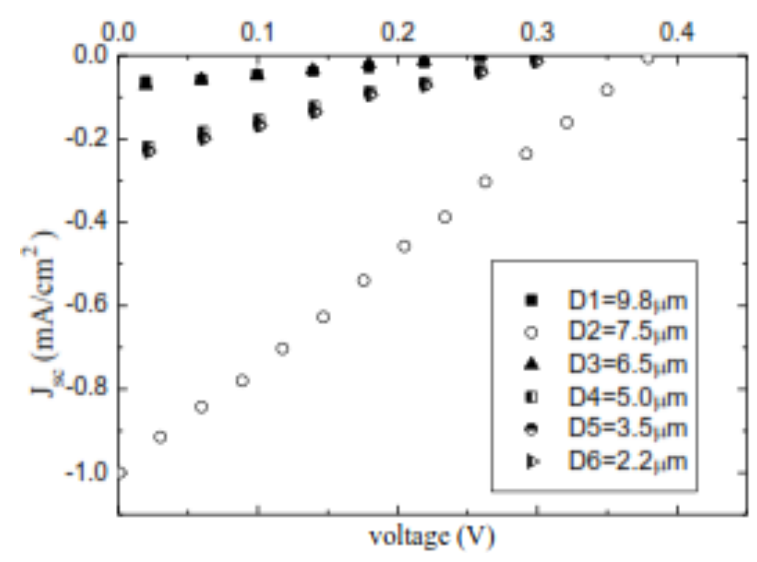

(b)

Fig. 3. (a) Current density voltage of DSSC at various sintering temperatures; (b) Current density voltage of DSSC at various photo electrode thicknesses 
Table 1

Application of natural dyes for dyes sensitizer

\begin{tabular}{|c|c|c|c|c|c|}
\hline Material & $\eta(\%)$ & $\mathrm{Isc}(\mathrm{mA}) / \mathrm{cm}^{2}$ & $V_{o c}(m V)$ & Fill Factor (\%) & Reference \\
\hline Pomegranate & 2 & 12.2 & 390 & 0.41 & Ghan et al., \\
\hline Blackberry & 1.4 & 11.16 & 470 & 0.26 & [13] \\
\hline Cranberry & 1.2 & 6.78 & 410 & 0.42 & \\
\hline Blueberry & 0.4 & 2.72 & 420 & 0.38 & \\
\hline Spinach & 0.171 & 0.41 & 590 & 58.76 & Ammar et \\
\hline Onion Red cabbage & 0.064 & 0.24 & 480 & 46.63 & al., [14] \\
\hline Spinach & 0.060 & 0.21 & 510 & 46.61 & \\
\hline Maqui & 0.0006 & & 60 & 4.73 & Cerda et al., \\
\hline Black Myrtle & 0.04 & & 40 & 4.89 & {$[15]$} \\
\hline Spinach & 0.005 & & 10 & 3.03 & \\
\hline Spinach - Black Myrtle & 0.009 & & 39 & 0.59 & \\
\hline Papaya Peel & 0.093 & 0.232 & 576 & 69.5 & $\begin{array}{l}\text { Orona- } \\
\text { Navar et al., } \\
{[16]}\end{array}$ \\
\hline Malabar spinach seeds & 9.23 & & 0.71 & 0.487 & Das et al., \\
\hline Red Spinach & 4.69 & & 0.505 & 0.514 & [17] \\
\hline Pomegranate & 3.08 & & 0.41 & 0.479 & \\
\hline Amaranthus caudatus & 0.610 & 1.82 & 0.55 & 61 & Godibo et \\
\hline Bougainvillea spectabilis & 0.325 & 1.11 & 0.5 & 58.6 & al., [18] \\
\hline Delonix regia & 0.031 & 0.114 & 0.47 & 57.9 & \\
\hline Nerium oleander & 0.013 & 0.046 & 0.5 & 57.5 & \\
\hline Spathodea companulata & 0.003 & 0.013 & 0.46 & 44 & \\
\hline Safflower & 0.100 & 1 & 0.390 & 24 & El-Ghamri \\
\hline Senna & 0.039 & 0.37 & 0.371 & 30 & et al., [20] \\
\hline Roselle & 0.004 & 0.08 & 0.259 & 23 & \\
\hline Rheum & 0.022 & 0.31 & 0.259 & 27 & \\
\hline Calumus draca & 0.030 & 0.31 & 0.348 & 28 & \\
\hline Carya illnoensis & 0.025 & 0.46 & 0.229 & 18 & \\
\hline Runica granatum & 0.010 & 0.23 & 0.300 & 21 & \\
\hline Rosa damascena & 0.009 & 0.28 & 0.170 & 20 & \\
\hline Black Rice & & & 0.551 & 0.52 & Hao et al., \\
\hline Erythrina & & & 0.484 & 0.55 & [21] \\
\hline Variegata & & & 0.492 & 0.52 & \\
\hline Rosa xanthina & & & 0.441 & 0.62 & \\
\hline Kelp & & & 0.412 & 0.63 & \\
\hline Capsicum & & & 0.682 & 0.67 & \\
\hline
\end{tabular}

The advantages of natural dyes as sensitizer can be described as follows

i. The application of natural dyes is a promising development in this field of technology. The revival of natural dyes occurred in the last two decades, along with the increase of costumer awareness of environmentally friendly products and technologies. The emergence of carcinogenic issues possessed by synthetic dyes strengthens the position of natural dyes.

ii. Natural dyes reduce the high cost of metal complex sensitizers and replace expensive chemical synthesis processes through a simple extraction process. Abundant natural dyes, easy to extract and safe ingredients thus harmless to environment. It can be extracted from flower petals, leaves, roots and bark in the form of anthocyanin pigments, carotenoids, flavonoids and chlorophyll.

iii. In addition, the production of natural dyes requires only a simple procedure so as to reduce costs. 
On the other hand, the disadvantages of natural dyes as sensitizer are as follows

i. One of the main obstacles in the utilization of natural dyes is the long extraction process. Conventionally, raw materials of natural dyes are selected according to the required characteristics. After going through the sorting process, the material must be cleaned and crushed, then extracted.

ii. Apart from the long process, the stability of dye extract is another problem that it must be immediately used after preparation. The distribution process of dye extract is also a serious problem. The colors produced by natural dyes are unrepeatable that for large-scale production, uniform colors are unreachable.

\section{Alternative Natural Dyes Powder}

The use of natural dyes as sensitizers has been studied; however, it has not reached optimal results. DSSC efficiency could be increased by using a dye solution with controlled concentrations. It is expected that by applying natural dyes powder as a sensitizer, the problem can be solved.

The unstable nature of natural dyes extract that is in liquid form makes it must be immediately used. Therefore, ready-to-use natural dyes and can be stored longer are needed to be applied according to the required concentration, with a relatively short preparation process and stable properties. The presence of natural dyes powder has practical characteristics like synthetic dyes powder.

New coloring methods were developed to achieve a standardized process. The combination of application of natural ingredients as well as modern technology to produce natural dyes powder generates a practical and environmentally friendly product. Studies regarding the conversion of extracts into natural dye powders have been carried out $[22,23]$. In these researches, natural dyes powder applied as a textile dye was produced. They generated stable natural dyes powder with a uniform color. In addition to textiles, good quality natural dyes powder is possible to be applied to solar cells as a medium for sunlight absorption.

To produce purified dye powders, the dye must first be extracted from the raw materials and the obtained extract is then concentrated or dried to obtain a liquid or powder concentrate that is ready for use. The extraction process is governed by various factors such as type and concentration of solvent, temperature, extraction time, and particle size of raw materials. Production process of natural dyes powder is given in Figure 4. 


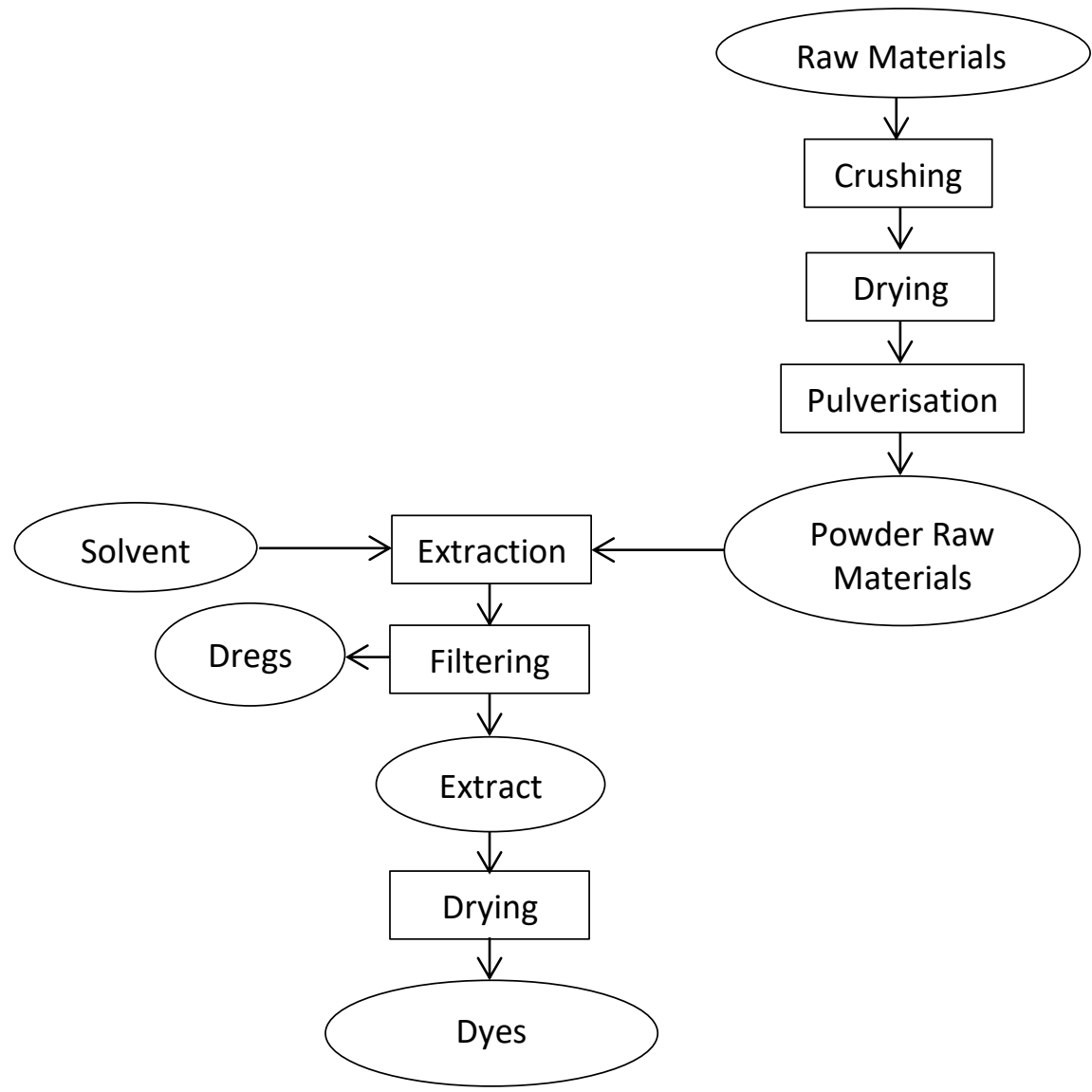

Fig. 4. Production process of natural dyes powder [24]

Natural dyes extraction method is determined based on the availability of equipment, as well as the advantages and disadvantages of the method. The most widely used methods are extraction, fermentation, and solvent extraction [25]. The extraction methods are described as follows

\section{i. Conventional extraction}

This is the simplest method; however, it requires long time, large container, and high temperature. Parameters and operating conditions during the extraction process, i.e., type and volume of solvent and extraction time, need to be taken into account to produce high extraction efficiency. The extraction process with water as solvent is carried out at temperature of $90-100^{\circ} \mathrm{C}$ [26-28]. The extract must be filtered to separate the dregs which can contaminate the textile material. In automatic machines, it can clog pumps and spinnerets. In addition, low density raw materials require large processing volumes.

\section{ii. Fermentation}

The fermentation method does not require high temperatures, but it may take longer time. The growth of bacteria during fermentation causes an unpleasant odor. Fermentation refers to the use of bacteria to form lactic acid. The extraction of indigo dye is carried out through fermentation process. During fermentation, indicans in the leaves are hydrolyzed to form indoxyl and glucose through endogenous $\beta$-glucosidase which followed by oxidation process to form indigo as the impact of air contact [29]. Fermentation reduces insoluble material of indigotin to be soluble material of alkaline. Fermentation could enhance the color fastness [30]. 


\section{iii. Solvent extraction}

Solvent extraction could optimally generate natural dye at a lower temperature thus minimizing fiber breakdown. However, the use of solvents results in the environmentally unfriendly dyeing method. Solvent extraction is reported to reduce dyeing costs with excellent color strength [31,32]. The raw material is extracted in a suitable solvent and then heated in a water bath for 1 hour at the boiling temperature of the solvent.

\section{iv. Ultrasound extraction}

Ultrasound-assisted extraction can be performed at lower temperatures thereby preventing thermal damage. This process is more efficient due to the mechanical influence of acoustic cavitation which increases mass transfer and solvent penetration in the raw material by breaking down the cell walls [33-35].

\section{v. Microwave extraction}

Microwaves are widely used in extraction due to their ability to generate high heat, increase the reaction rate, and decrease the reaction time $[27,36]$. This technology is also able to significantly increase product yield and quality. Ramadevi and Kalaiarasi [37] revealed that this method is simple, environmentally friendly, and economical for extracting biologically active compounds from plants. The minimal use of organic solvents put this method as a green technology. Microwaves increase the mass transfer of dyes from raw materials of plant to the solvent medium [38].

After the extraction of raw material, the obtained natural dye solution is then dried to produce the dye powder. The following are some of the commonly used drying technologies.

\section{vi. Spray drying}

Spray drying is the most common simple and cheap method for converting dye extracts to powder form. The extract is sprayed into the storage tank through a fine-grained spray nozzle. There is contact between the blown hot air in the tank with fine grains thus evaporates the solvent. The obtained dry particles drop at the bottom of the tank. This method can be applied to heat-stable dye molecules because the dry powder of the dye will come into direct contact with hot air [25,39-42]. Spray drying process is done by spraying extract solution into the drying chamber. This process could be applied for materials that are soluble in organic solvents. The liquid is atomized using a nozzle; the tiny liquid droplets are dispersed and contacted with hot air. The droplet dries quickly and falls to the bottom of the dryer. This rapid evaporation process generates low grain temperatures that could apply high drying temperatures without affecting product quality. The low product temperatures as well as the short drying times allow spray drying to be utilized for heat sensitive products. Research on application of spray dryer was done by Delvitasari [24] as illustrated in Figure 5. 


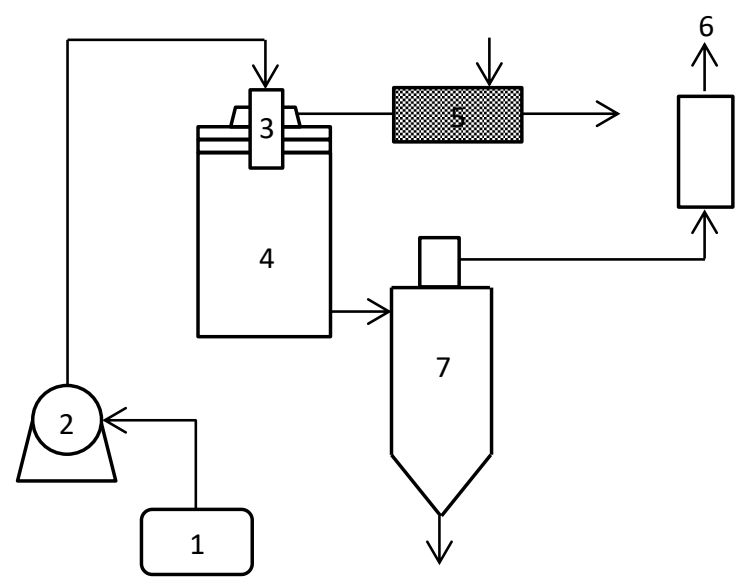

1. Material

2. Pump

3. Atomizer

4. Chamber

5. Heater

6. Air

7. Cyclon

Fig. 5. Schematic diagram of spray drying process [24]

Prasetyo et al., [43] investigated the energy consumption of spray dryer machine for the production of natural dyes powder from Caesalpinia Sappan Linn wood as shown in Figure 6. Prior to the process, the reactor is heated to a temperature of $90^{\circ} \mathrm{C}$. The compressor generates pressurized air to spray the solution through the nozzle into the reactor. The mist is vaporized with hot air from inlet blower inside the reactor. The water vapor and dry powder are flowed and separated in cyclone A, B, and C. The formed dye powder is collected in the cyclone A, B and C.

vii. Vacuum drying

The extract can be concentrated under vacuum with a rotary evaporator. The dye concentrate can be further purified by various solvents $[25,44,45]$.

viii. Freeze drying

In this process, the natural dye extract is frozen and water is removed from the frozen extract through a sublimation process by lowering the pressure. This equipment is relatively expensive with high operating costs. However, this process is beneficial in term of low process temperature. The conversion of dye extract into powder is harmless for heat sensitive dye molecules can be turned into a powder at the freezing point $[32,42,46,47]$.

The advantages of natural dyes powder for sensitizer application can be described as follows

i. Natural dyes in form of solid or powder generated stable and uniform color characteristics. In addition to textiles, good quality natural dyes powder is possible to be applied to solar cells as a medium for sunlight absorption [48].

ii. Natural dyes powder offers beneficial in the durability and simplicity of storage and distribution. The generated color is more uniform; moreover, in the form of powder, it provides much more stable dyes due to the very low water content [48].

On the other hand, natural dyes powder needs longer production process compared to the liquid form as it still further processed via drying process. As a consequence, production cost becomes increase.

Based on the description above, research on utilization of natural dyes powder as sensitizers is believed to be prospective in contributing to knowledge and technology. Application of natural dyes 
powder is able to control sensitizer concentration thus generating qualified DSSC. Dye standardization plays an important role in minimizing DSSC variability due to the different characteristics of raw materials.

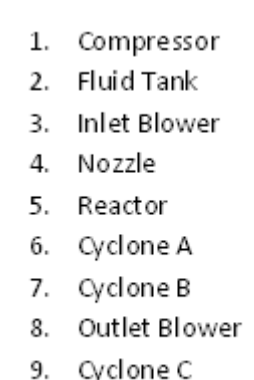

(3)

2. Fluid Tank

3. Inlet Blower

4. Nozzle

Reactor

. Cyclone A

. Cyclone B

9. Cyclone $\mathrm{C}$
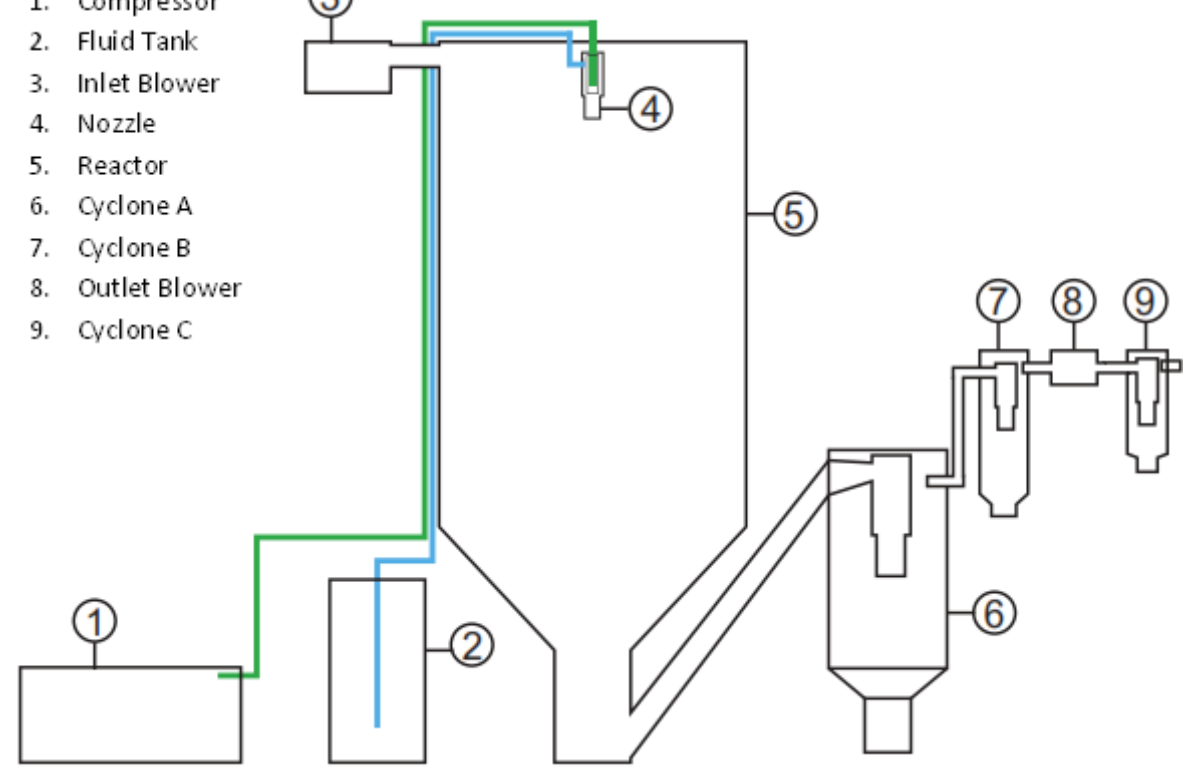

Fig. 6. Schematic diagram of spray dryer machine [43]

\section{Conclusions}

Natural dyes offer a promising sensitizer material for Dyes-Sensitized Solar Cell application. It plays an important role in absorbing sunlight and converting solar energy into electric energy. The performance of DSSC mainly depends on the dye used as a sensitizer. Although natural dyes still have lower cell efficiency than metal-based sensitizers, they are environmentally friendly, low production costs, and energy efficient. It is believed that the efficiency of DSSC could be increased by using a dye solution with controlled concentrations. In this concern, instead of liquid natural dyes extract, natural dyes powder can be an alternative for dye sensitizer as it has stable properties, can be stored for a long time, and more importantly it can be used anytime. So that, production and application of natural dyes powder for DSSC is important to be further studied.

\section{Acknowledgement}

Applied research grant funded by the Ministry of Education and Culture of the Republic of Indonesia is gratefully acknowledged.

\section{References}

[1] National Energy Council. "Report of National Energy Council." Jakarta: National Energy Council (2014).

[2] Obane, Hideaki, Yu Nagai, and Kenji Asano. "Assessing land use and potential conflict in solar and onshore wind energy in Japan." Renewable Energy 160 (2020): 842-851. https://doi.org/10.1016/i.renene.2020.06.018

[3] Islam, Md. Fakhrul, Nadhrah Md Yatim, and Mohd Azman Hashim@Ismail. "A Review of CZTS Thin Film Solar Cell Technology." Journal of Advanced Research in Fluid Mechanics and Thermal Sciences 81, no. 1 (2021): 73-87. https://doi.org/10.37934/arfmts.81.1.7387

[4] Rahardjo, I., and I. Fitriana. "Analisis Potensi Pembangkit Listrik Tenaga Surya di Indonesia." National Electricity Supply Strategy in Anticipating the Utilization of Small-Scale Coal Steam Power Plants, Nuclear Power Plants, and Renewable Energy (2005). http://www.geocities.ws/markal bppt/publish/pltkcl/pl rahard.pdf. 
[5] Gamry. "DSSC: Dye Sensitized Solar Cells - Basic Principles and Measurements." Gamry Instruments, 2021. https://www.gamry.com/application-notes/physechem/dssc-dye-sensitized-solar-cells/.

[6] Akila, Y., N. Muthukumarasamy, and Dhayalan Velauthapillai. "TiO2-based dye-sensitized solar cells." In Nanomaterials for Solar Cell Applications, pp. 127-144. Elsevier, 2019. https://doi.org/10.1016/B978-0-12-813337$\underline{8.00005-9}$

[7] Narayan, Monishka Rita. "Dye sensitized solar cells based on natural photosensitizers." Renewable and Sustainable Energy Reviews 16, no. 1 (2012): 208-215. https://doi.org/10.1016/i.rser.2011.07.148

[8] Sekar, N., and Vishal Y. Gehlot. "Metal complex dyes for dye-sensitized solar cells: Recent developments." Resonance 15, no. 9 (2010): 819-831. https://doi.org/10.1007/s12045-010-0091-8

[9] Kafle, Bhim P., Babu R. Pokhrel, Rajendra Gyawali, Ananda Kafle, Tirtha M. Shrestha, Ramita Shrestha, and Ravi M. Adhikari. "Absorbance of natural and synthetic dyes: Prospect of application as sensitizers in dye sensitized solar cell." Advances in Applied Science Research 5, no. 1 (2014): 8-12.

[10] Al-Bat'hi, Souad Ali, Iraj Alaei, and lis Sopyan. "Natural photosensitizers for dye sensitized solar cells." International Journal of Renewable Energy Research (IJRER) 3, no. 1 (2013): 138-143.

[11] Chiba, Yasuo, Ashraful Islam, Yuki Watanabe, Ryoichi Komiya, Naoki Koide, and Liyuan Han. "Dye-sensitized solar cells with conversion efficiency of 11.1\%." Japanese Journal of Applied Physics 45, no. 7L (2006): L638. https://doi.org/10.1143/JJAP.45.L638

[12] Richhariya, Geetam, Anil Kumar, Perapong Tekasakul, and Bhupendra Gupta. "Natural dyes for dye sensitized solar cell: A review." Renewable and Sustainable Energy Reviews 69 (2017): 705-718. https://doi.org/10.1016/j.rser.2016.11.198

[13] Ghann, William, Hyeonggon Kang, Tajbik Sheikh, Sunil Yadav, Tulio Chavez-Gil, Fred Nesbitt, and Jamal Uddin. "Fabrication, optimization and characterization of natural dye sensitized solar cell." Scientific Reports 7, no. 1 (2017): 1-12. https://doi.org/10.1038/srep41470

[14] Ammar, Ahmed M., Hemdan SH Mohamed, Moataz MK Yousef, Ghada M. Abdel-Hafez, Ahmed S. Hassanien, and Ahmed SG Khalil. "Dye-sensitized solar cells (DSSCs) based on extracted natural dyes." Journal of Nanomaterials 2019 (2019). https://doi.org/10.1155/2019/1867271

[15] Cerda, Bayron, R. Sivakumar, and M. Paulraj. "Natural dyes as sensitizers to increase the efficiency in sensitized solar cells." In Journal of Physics: Conference Series, vol. 720, no. 1, p. 012030. IOP Publishing, 2016. https://doi.org/10.1088/1742-6596/720/1/012030

[16] Orona-Navar, A., I. Aguilar-Hernández, T. López-Luke, I. Zarazúa, V. Romero-Arellano, J. P. Guerrero, and N. OrnelasSoto. "Photoconversion efficiency of Titania solar cells co-sensitized with natural pigments from cochineal, papaya peel and microalga Scenedesmus obliquus." Journal of Photochemistry and Photobiology A: Chemistry 388 (2020): 112216. https://doi.org/10.1016/j.jphotochem.2019.112216

[17] Das, Sujan Kumar, Sumon Ganguli, Humayun Kabir, Jahirul Islam Khandaker, and Farid Ahmed. "Performance of Natural Dyes in Dye-Sensitized Solar Cell as Photosensitizer." Transactions on Electrical and Electronic Materials 21, no. 1 (2020): 105-116. https://doi.org/10.1007/s42341-019-00158-y

[18] Godibo, Desalegn J., Sisay T. Anshebo, and Teketel Y. Anshebo. "Dye sensitized solar cells using natural pigments from five plants and quasi-solid state electrolyte." Journal of the Brazilian Chemical Society 26 (2015): 92-101. https://doi.org/10.5935/0103-5053.20140218

[19] Iqbal, Muhammad Zahir, Syeda Ramsha Ali, and Sana Khan. "Progress in dye sensitized solar cell by incorporating natural photosensitizers." Solar Energy 181 (2019): 490-509. https://doi.org/10.1016/j.solener.2019.02.023

[20] El-Ghamri, Hatem S., Sofyan A. Taya, Taher M. El-Agez, Amal M. Al-Kahlout, Naji Al Dahoudi, and Monzir S. AbdelLatif. "Natural Dyes as Photosensitizers for Dye-sensitized Solar Cells." Journal of Nano-and Electronic Physics 7, no. 3 (2015): 3001-1.

[21] Hao, Sancun, Jihuai Wu, Yunfang Huang, and Jianming Lin. "Natural dyes as photosensitizers for dye-sensitized solar cell." Solar Energy 80, no. 2 (2006): 209-214. https://doi.org/10.1016/i.solener.2005.05.009

[22] Kusumastuti, Adhi, Samsudin Anis, and Dewi Selvia Fardhyanti. "Production of natural dyes powder based on chemo-physical technology for textile application." In IOP Conference Series: Earth and Environmental Science, vol. 258, no. 1, p. 012028. IOP Publishing, 2019. https://doi.org/10.1088/1755-1315/258/1/012028

[23] Kusumastuti, Adhi, Dewi Selvia Fardhyanti, and Samsudin Anis. "Brachiaria mutica dyes powder for textile application: dyeing quality of cotton fabrics." In Journal of Physics: Conference Series, vol. 1444, no. 1, p. 012010. IOP Publishing, 2020. https://doi.org/10.1088/1742-6596/1444/1/012010

[24] Delvitasari, Febrina. "Design Process of Extraction and Natural Dye Powder Production from Swietenia mahagoni and its Application in Textile Dyeing." Teknologi Industri Pertanian, Institut Pertanian Bogor, Bogor (2013).

[25] Saxena, Sujata, and A. S. M. Raja. "Natural dyes: sources, chemistry, application and sustainability issues." In Roadmap to Sustainable Textiles and Clothing, pp. 37-80. Springer, Singapore, 2014. https://doi.org/10.1007/978981-287-065-0 2 
[26] Bechtold, Thomas, Amalid Mahmud-Ali, and Rita Mussak. "Natural dyes for textile dyeing: A comparison of methods to assess the quality of Canadian golden rod plant material." Dyes and Pigments 75, no. 2 (2007): $287-293$. https://doi.org/10.1016/j.dyepig.2006.06.004

[27] Hassan, Rodiah Mohd, Asma Fadhilah Zulrushdi, Aziah Mohd Yusoff, Nobuyuki Kawasaki, and Noor Asiah Hassan. "Comparisons between Conventional and Microwave-Assisted Extraction of Natural Colorant from Mesocarp and Exocarp of Cocus Nucifera." Journal of Materials Science and Engineering B 5, no. 3-4 (2015): 152-158. https://doi.org/10.17265/2161-6221/2015.3-4.006

[28] Swami, Charu, Sangita Saini, and V. B. Gupta. "Extraction of a natural dye from Sesbania aculeata plant." Journal of Textile and Apparel, Technology and Management 7, no. 4 (2012).

[29] Comlekcioglu, Nazan, Lale Efe, and Sengul Karaman. "Extraction of indigo from some Isatis species and dyeing standardization using low-technology methods." Brazilian Archives of Biology and Technology 58 (2015): 96-102. https://doi.org/10.1590/S1516-8913201502658

[30] Makkar, Priya. "Dye extraction from plant sources through fermentation technique for silk dyeing." PhD diss., Chaudhary Charan Singh Haryana Agricultural University; Hisar, 2010.

[31] Morshed, Mohammad Neaz, Hridam Deb, S. Al Azad, M. Z. Sultana, and A. K. Guha. "Aqueous and solvent extraction of natural colorants from Tagetes erecta L., Lawsonia inermis, Rosa L for coloration of cellulosic substrates." American Journal of Polymer Science and Technology 2, no. 2 (2016): 34-39.

[32] Ngo, J. S. K., W. F. Ong, F. B. Ahmad, and K. B. Bujang. "A Study of Soluble-Powdered Natural Dyes." Research Journal of Textile and Apparel 17, no. 1 (2013): 104-112. https://doi.org/10.1108/RJTA-17-01-2013-B011

[33] Rouhani, Sh, Naader Alizadeh, Shabnam Salimi, and Tahere Haji-Ghasemi. "Ultrasonic Assisted Extraction of Natural Pigments from Rhizomes of Curcuma Longa L." Progress in Color, Colorants and Coatings 2, no. 2 (2009): 103-113.

[34] Zhong, Zhang. "Optimization of ultrasound-assisted extraction conditions of flavonoids from tartary buckwheat." Journal of Pharmaceutical and Scientific Innovation (JPSI) 1, no. 6 (2012): 39-43.

[35] Sheikh, Javed, Priyanka S. Jagtap, and M. D. Teli. "Ultrasound assisted extraction of natural dyes and natural mordants vis a vis dyeing." Fibers and Polymers 17, no. 5 (2016): 738-743. https://doi.org/10.1007/s12221-016$\underline{5031-0}$

[36] Zulrushdi, Nur Asma Fhadhila, Rodiah Mohd Hassan, and Aziah Mohd Yusoff. "Microwave-assisted extraction of natural colorant extracted from mesocarp and exocarp of Cocos nucifera (coconut palm)." European Journal of Biotechnology and Bioscience 4, no. 4 (2016): 1-5. https://doi.org/10.17265/2161-6221/2015.3-4.006

[37] Ramadevi, S., and K. Kalaiarasi. "Optimization of microwave-assisted extraction of natural dye from Ricinus communis L leaves." International Journal of Advanced Science and Engineering 2 (2015): 98-102.

[38] Sinha, Keka, Shamik Chowdhury, Papita Das Saha, and Siddhartha Datta. "Modeling of microwave-assisted extraction of natural dye from seeds of Bixa orellana (Annatto) using response surface methodology (RSM) and artificial neural network (ANN)." Industrial Crops and Products 41 (2013): $165-171$. https://doi.org/10.1016/j.indcrop.2012.04.004

[39] Değirmenci, Duygu, Birkan Salim Yurdakul, Tuğçe Uysal, and Tülin Aşkun. "Dyeing of Cotton Fabrics Using Natural Dyes Obtained by Spray Dryer Method." In XIIIth International Izmir Textile and Apparel Symposium, p. 177-180. 2014.

[40] Manuel, J. "Storage Characteristics of the Spray Dried Talisay (Terminalia catappa) Leaves as Source of Natural Dye." Journal of Textile Science \& Engineering 7, no. 6 (2017): 326.

[41] Seino, Junzaburo, Hiroshi Ikeda, Washohati Abo, Iwao Minami, and Joji Fuji. "Production of dyestuff powders." U.S. Patent 4,362,273, issued December 7, 1982.

[42] Antigo, Jéssica Loraine Duenha, Rita de Cassia Bergamasco, and Grasiele Scaramal Madrona. "Effect of pH on the stability of red beet extract (Beta vulgaris L.) microcapsules produced by spray drying or freeze drying." Food Science and Technology 38 (2017): 72-77. https://doi.org/10.1590/1678-457x.34316

[43] Prasetyo, Singgih Dwi, Catur Harsito, Sutanto, and Suyitno. "Energy consumption of spray dryer machine for producing red natural powder dye and its stability." In AIP Conference Proceedings, vol. 2097, no. 1, p. 030076. AIP Publishing LLC, 2019. https://doi.org/10.1063/1.5098251

[44] Samanta, Ashis Kumar, and Adwaita Konar. "Dyeing of Textiles with Natural Dyes." In Natural Dyes. IntechOpen, 2011.

[45] Singh, Vijender, Mohammed Ali, and Sukirti Upadhyay. "Study of colouring effect of herbal hair formulations on graying hair." Pharmacognosy Research 7, no. 3 (2015): 259. https://doi.org/10.4103/0974-8490.157976

[46] Papadaki, Sofia, Magdalini Krokida, Dimitrios Economides, and Emmanuel Koukios. "Effect of drying methods on dyeing capacity of dyestuff plant materials." Drying Technology 32, no. 12 (2014): 1500-1511. https://doi.org/10.1080/07373937.2014.903409 
[47] Basitah, T. "Extraction, characterization and application of natural dyes from the fresh rind of index colour 5 mangosteen (Garcinia mangostana L.)." International Journal of Chemical and Molecular Engineering 9, no. 7 (2015): 883-886.

[48] Kusumastuti, A., D. S. Fardhyanti, S. Anis, and A. Kamis. "Production of Brachiaria mutica as natural dyes powder for textile application: characterisation study." In IOP Conference Series: Earth and Environmental Science, vol. 700, no. 1, p. 012033. IOP Publishing, 2021. https://doi.org/10.1088/1755-1315/700/1/012033 